\title{
DRŽAVNA ŠKOLSKA POLIKLINIKA U PETRINJI (1925. - 1945.)
}

\author{
STATE SCHOOL - POLYCLINIC \\ IN PETRINJA (1925-1945)
}

\author{
Boris Vrga*, Tatjana Vrga*
}

\begin{abstract}
SAŽETAK
Na temelju arhivskih dokumenata i literaturnih podataka istraženo je i rekonstruirano djelovanje Državne školske poliklinike u Petrinji u razdoblju od njezina osnutka 1925. do prestanka postojanja 1945. $i$ apostrofirani su ključni nositelji njezine djelatnosti. Osnovana kao jedna od prvih školskih poliklinika u Hrvatskoj, petrinjska Državna školska poliklinika razvila je cjelovitu preventiunu i kuratiunu zdravstvenu djelatnost kod petrinjske školske populacije i učenika seoskih škola petrinjskog kotara. Njezino neprekidno dvadesetogodišnje djelovanje na zdravstvenoj zaštiti školske populacije uspjela je sinteza preventivnih $i$ kurativnih zdravstvenih načela utemeljenih na naprednim idejama socijalne medicine Andrije Štampara, promotora i reformatora javnoga zdravstva na našim prostorima. Promičući cjelovitu zdravstvenu skrb, čuvajući i unaprjeđujući tjelesno i duševno zdravlje djece i mladeži petrinjskih $i$ okolnih škola, podignula je ugled petrinjskog zdravstva i pridonijela razvoju hrvatske školske medicine.
\end{abstract}

Ključne riječi: dentalna medicina; dr. Bogdan Vorkapić; dr. Oskar Štern; dr. Rudolf Herceg; javno zdravstvo; školska medicina; školska poliklinika Petrinja.

\section{Uvod}

Da školska populacija ima svoje zdravstvene specifičnosti koje su, između ostaloga, inicirane uvjetima boravka u školi te nepovoljnim fizičkim i

" Opća bolnica „Dr. Ivo Pedišić“, Sisak - lokacija Petrinja.

Adresa za dopisivanje: Boris Vrga, Opća bolnica „Dr. Ivo Pedišićc, Sisak - lokacija Petrinja, Vinogradibb, 44250 Petrinja.E-pošta: vrgaboris@gmail.com. 
psihosocijalnim učincima nastalim tijekom školovanja, poznato je u Europi još od kraja XVIII. stoljeća kada je u Francuskoj 1793. donesen zakon o pregledavanju školske djece. ${ }^{1}$ U XIX. stoljeću i druge su europske zemlje počele uvoditi službu školskih liječnika, a njihova iskustva u Hrvatskoj problematiziraju se tek krajem XIX. stoljeća.

Da je zdravstvena skrb školske djece postala u to vrijeme predmet širega društvenog interesa dokaz je sve veći broj zakona, naputaka i odredbi koje donose nadležna državna tijela. Slijedom toga, Kr. hrv.-slav.-dalm. zemaljska vlada donijela je 1872 . Naputak kako treba da se postupa prigodom vladajuće među pučanstvom pošasti u obće, a kolere napose kojim se stanovništvo i školske uprave upoznaju s mjerama koje treba poduzeti radi sprječavanja i suzbijanja raznih zaraznih bolesti, poglavito kolere², a I875. Naputak za podžupanijske liječnike i gradske fizike kojim se ti liječnici zadužuju za zdravstveni nadzor nad školama i školskom djecom. ${ }^{3}$ Nedugo potom, i883., objavljena je i Naredba o nadziranju pučkih škola pod zdravstvenim organima kojom se liječnici uključuju u komisije za izgradnju i pregradnju škola te mjesne školske odbore koji se brinu o zdravlju djece. ${ }^{4}$

Naredbom od I5. srpnja I889. definirane su osnove prirodopisa za učiteljske škole kojima je uveden nauk o čovjeku i ,nutarnjem ustrojstvu čovječjega tijela, njegovu životu i razvitku s obzirom na zdravoslovlje, osobito školsko“. Istom naredbom regulirani su higijenski propisi za sve škole u Hrvatskoj, propisi o tjelovježbi, raskuživanju od pošasnih bolesti te mjere sprječavanja zaraznih bolesti. Slijedom toga naloženo je da „djeca bolujuća od kakove priljepčive bolesti ne smiju, dok bolest traje i pogibelj priljepa ne umine, polaziti škole“5. Godine r8gr. donesen je zakon o cijepljenju protiv boginja ${ }^{6}$, a I894. zakon o uređenju zdravstvene službe. ${ }^{?}$

1 M. Lončar-Dušek: 70 godina prvog školskog ambulatorija (1923. - 1993.), 100 godina prvog školskog liječnika u Hrvatskoj, 200 godina školske medicine u Europi, „Pediatria Croatica“, 1994; 38; 51-53.

2 HR -DASK - SACP - 122 Realna gimnazija Petrinja. Postupanje u slučaju pojave zaraznih bolesti, posebice kolere, kutija 5, br. 8606 (1872.)

3 Naredba br. 2949 od 24. kolovoza 1875., kojom se izdaju naukovne osnove za obće pučke i građanske škole u kraljevinah Hrvatskoj i Slavoniji, „Narodne novine“, 1875;11.

4 M. Smrekar: Priručnik za političku upravnu službu u kraljevinah Hrvatskoj i Slavoniji, Zagreb, 1899., knjiga I: 83

5 Sbirka zakona i naredaba tičućih se zdravstva i zdravstvene službe. Naredba kr. zemaljske vlade od 7. ožujka 1899. godine, br. 40.563 ex 1888., kojom se izdaje naputak kako valja zapriječiti u školah prijenos kužnih bolesti, V. Katačić (prir.), Zdr. odsj. kr. zem. vl., II. izdanje, Zagreb, 1906; 431.

6 Isto. Zakon o cieplienju i dociepljivanju boginja od 6. srpnja 1891; 460-463.

7 Isto. Zakon o uređenju zdravstvene službe u kr. Hrv. i Slav. od 24. siječnja 1894; 1-8. 
Daljnji korak u uspostavi redovitoga zdravstvenog nadzora nad zdravljem učenika i što efikasnijeg očuvanja njihova zdravlja, bio je postavljanje školskih liječnika u pojedine škole pa je tako prvi školski liječnik u Hrvatskoj imenovan na gimnaziji i realki u Zagrebu r893. godine. ${ }^{8}$

Nastojanja vezana za zdravstvenu zaštitu školske djece Kr. zemaljska vlada, Odjel za unutrašnje poslove, objelodanila je u dopisu od 27. svibnja Igor., zaključujući kako bi bilo poželjno „da se i u našoj zemlji toj velikoj potrebi školskog zdravstva pomogne imenovanjem dovoljnog broja školskih liječnika kojih bi broj imao biti u shodnom razmjerju prema broju učenika, jer inače ne bi bilo moguće da takav liječnik svojoj zadaći udovolji. No, pošto se djelatnost takovih školskih liječnika ne bi mogla u toliko protegnuti na seoske pučke škole, koli na gradske, misli zdravstveno vijeće, da se u školske čitanke uvrste higienska štiva u kojima bi valjalo školsku djecu poučiti o sačuvanju svih tjelesnih ustroja, dakle i o njezi i sačuvanju zubi"9.

Osim što je 1908. uvedena nauka o zdravlju kao obligatan predmet u zadnjem razredu srednjih škola u cijeloj zemlji, sve do završetka Prvoga svjetskog rata nije se uspjela organizirati efikasna zaštita zdravlja školske djece. Tek krajem rata, I9I8., Zdravstveni odsjek zem. vlade izdao je Naputak za školske liječnike srednjih $i$ sličnih škola, kojim su precizno definirane preventivne i kurativne mjere koje su dužni provoditi. Prema Naputku,,školski liječnik je dužan da svakog učenika gleda i to svestrano glede ustroja u opće, glede vida i sluha, zubi i probavila, disala i kostura. Nalaz o toj pregledbi mora školski liječnik unijeti u matični zdravstveni list. One kod kojih je bolest našao pregledava opetovano da vidi jeli bolest kreće na bolje ili gore. Od vremena do vremena mora pohađati pojedine razrede da se osvjedoči nije li koji od učenika bolestan od kakove zarazne bolesti, jeli veličina sobe odgovara broju učenika, jeli ventilacija školskih soba u redu. Imade pravo doći na svaku sjednicu učiteljskog zbora te $s$ učiteljima raspravljati o svojim opažanjima o zdravstvenom stanju učenika i školske zgrade, a mora podnositi godišnja izvješća o svome radu“10. Istodobno, Odjel za bogoštovje i nastavu počeo je namještati školske liječnike u cijeloj zemlji, s napomenom da od početka školske godine svaka muška i ženska srednja škola mora imati svoga liječnika. ${ }^{11}$

8 Isto. Naredba kr. hrv-slav.dalmatinske vlade, odjela za bogoštovje i nastavu od 18. studenog 1893., br. 15631 kojom se za kr. gimnaziju i kr. realku zagrebačku određuje školski liječnik.

9 R. Marković: Školski liječnici, „Liječnički vjesnik“, 1906; 7; 265.

10 F. Vitauš: Školski liječnici za srednje i slične škole u Hrvatskoj i Slavoniji, „Liječnički vjesnik“, 1919; 9; 469-470.

11 Isto. 
Znanstvena saznanja o značenju zaštite zdravlja školske djece rezultirala su otvaranjem prvoga školskog ambulatorija u Zagrebu 1923., a nedugo potom i prve Školske poliklinike koja je započela s radom u Zagrebu 6. listopada 1924. godine. ${ }^{12}$ Njezino djelovanje bilo je regulirano Pravilnikom o radu školskih poliklinika prema kojemu su ove ustanove "osnovane u cilju socijalno-higijenske i zdravstvene zaštite djece školskog doba“, sa zadaćom „da sistematskim i periodičnim pregledom sve školske djece iznalaze mentalne i tjelesne defekte koji sprječavaju dječji razvitak i napredovanje ${ }^{\text {“133 }}$.

Budući da je sedam mjeseci nakon Zagreba i u Petrinji osnovana Državna školska poliklinika, odlučili smo se da na temelju dostupnih arhivskih dokumenata pohranjenih u Hrvatskome državnom arhivu, Državnom arhivu u Sisku - Sabirnom centru Petrinja, godišnjim školskim izvješćima petrinjskih škola i ostalim literaturnim izvorima rekonstruiramo okolnosti njezina osnivanja i cjelokupno djelovanje.

\section{Petrinjsko šKolstvo I SLIKA ZdRAVLJA PETRINJSKiH UČENIKA PRIJE OSNIVANJA ŠKolske POLIKLINIKE}

Od krajiškog doba, Petrinja je poznata kao pedagoški centar Vojne krajine. Normalna škola (Normalschule) osnovana je u njoj 1774., Djevojačka 1776., Geometrijska 1777., a Glazbena škola ı841. godine. Mala realna gimnazija u gradu djeluje od I860., Učiteljska škola od I862., Šegrtska od I887., a Vinogradarsko-voćarska od 1893 . godine. ${ }^{14}$ Velik broj učenika u petrinjskim školama i razmjerno neodgovarajući uvjeti njihova smještaja (nedovoljan broj školskih zgrada, obavljanje obuke po cijeli dan, prenatrpanost razreda, nedostatak vremena za ozračivanje, pranje podova, čišćenje prašine i dr.) pogodovali su pojavi epidemija raznih zaraznih bolesti, npr. gripe i89o. od koje je „obolila trećina učenika i polovina učitelja tako da su na prijedlog gradskog fizika dr. Stjepana Modoša (I842. - I9I9.) bili raspušteni svi domaći naučni zavodi i da je na osam dana morala biti prekinuta obuka" ${ }^{\text {"15. }}$.

Potaknuto pojavom kolere u nedalekom Dvoru (oboljelo i6 osoba, umrlo sedam) i Jasenovcu (oboljelo 45 osoba, umrlo 17, među kojima i općinski

12 D. Hofgräff, S. Fatović-Ferenčić: Uloga i doprinos Desanke Ristović - Štampar (1882. - 1968.) razvoju Školske poliklinike u Zagrebu (1925. - 1941.), "Anali Zavoda za znanstveni i umjetnički rad u Osijeku“, Zagreb - Osijek, 2012; 28; 9-24.

13 „Službene novine“, 1924; 16; 80.

14 I. Golec: Povijest školstva u Petrinji 1700. - 2000., Petrinja, Matica hrvatska, 2000.; 41-42., 77. , $85-86 ., 100 ., 106 ., 280 ., 292$.

15 Influenza, „Banovac“, 1890; 3; 2. 
liječnik dr. Ferdo Hijsek), ${ }^{16}$ Gradsko poglavarstvo u Petrinji donijelo je I892. Odredbe i upute protiv kolere ${ }^{17}$ koje su bile uspješno provedene budući da u Petrinji nije zabilježen niti jedan slučaj ove bolesti.

Prema izvješću županijskog liječnika dr. Izidora Schlicka, podnesenom upravnom odboru Županije zagrebačke I893. „u cieloj ogromnoj zagrebačkoj županiji bijaše zdravstveno stanje najlošije u kotaru petrinjskom, glinskom i kostajničkom. U ovih kotarih vladale su infekciozne bolesti kao dobrac, difterija, krupozne užgaline ždriela i jabučice te influenca i hripavac. U kotaru Petrinja pojavio se dobrac (ospice, nap. a.) polovicom siječnja I892. i obuhvatio upravne općine Mečenčani, Gradusu, Sunju i Jabukovac. Do konca ožujka oboljelo je u kotaru 8Io djece, od kojih je 448 ozdravilo, 8I umrlo, a 28I preostalo je još bolesno"18.

Zbog ranih smrti u učiteljskom staležu, što je rezultiralo nedostatkom učiteljskog osoblja u Hrvatskoj, posvećeno je više pozornosti zdravstvenom stanju učiteljskih pripravnika od kojih mnogi „pohađaju učiteljsku školu u biedi i nevolji, u pomanjkanju knjiga i inih potrebština" ${ }^{\text {"19. }}$. Slijedom toga osnovano je I895. Društvo za podporu siromašnih učiteljskih pripravnika u Petrinji, za čijeg je predsjednika izabran Ignjat Kršnjavi. ${ }^{20}$

Rješenjem Visoke vlade, 7. prosinca I895. uvedeno je u petrinjsku Vinogradarsko-voćarsku školu zdravoslovlje kao poseban učevni predmet. Obuka iz tog predmeta povjerena je gradskom fiziku dr. Nikoli Žyborskom (I866. - 1917.) koji je ujedno predavao higijenu na mjesnoj učiteljskoj školi. Zbog pojave difterije i hripavca među školskom djecom, na njegov su prijedlog 15 . lipnja i895. zatvoreni kr. vježbaonica, djevojačka i šegrtska škola, a u veljači I896. i muška te ženska pučka škola jer su „ospice zarazile svaku kuću"21.

U srpnju I897. „bjesnio je u Maloj Gorici kraj Petrinje škrlet (šarlah, nap. a.) te prietila velika pogibelj da čitavo selo ostane bez djece". Epidemija je zahvatila i Petrinju u kojoj su oboljele 33 osobe, a I2 ih je umrlo. ${ }^{22}$

\footnotetext{
F. Potocka: Izksutva za kolere u Dvoru god. 1892., ,Liječnički vjesnik“, 1893; 3; 43.

Odredbe protiv kolere, „Banovac“, 1892; 43; 2.

Zdravstvene prilike u Baniji, „Banovac“, 1893; 26; 2-4.

1 Gj. Turić: Družtvo za podporu siromašnih učiteljskih pripravnika u Petrinji, „Banovac“, 1895; 1; $1-2$.

22 Zdravstvo prošle godine u Petrinji, „Banovac“,1898; 6; 1.
} 
Tijekom I898. u Petrinji je zabilježeno 30 slučajeva šarlaha, pri čemu je osmero djece umrlo, I2 slučajeva difterije, od koje je umrlo pet osoba, a hripavac se javio kod II djece, od kojih je dvoje podleglo. Od sušice su umrle 33 osobe, što je jedna trećina cjelokupnog pomora zabilježenog te godine u Petrinji. ${ }^{23}$

Godine 1905. pojavila se u Petrinji velika epidemija šarlaha koja je trajala od sredine rujna 1905. do sredine srpnja 1906. godine. Njome su bile zahvaćene 74 osobe, od kojih je I6 umrlo. Sve petrinjske škole bile su više mjeseci zatvorene ${ }^{24}$ pa je grad nekoliko puta posjetio kr. županijski fizik dr. Izidor Schlick da se "osvjedoči o stanju škrleti i mjerama koje su za ublaženje te bolesti poduzete" ${ }^{\text {"25 }}$.

Od početka Prvoga svjetskog rata 1914. do kraja rata 1917. u zgradi Učiteljske škole nalazila se rezervna, a u zgradi realne gimnazije privremena vojna bolnica. $U$ dvorištu tih škola podignute su 1915 . dvije barake za ranjenike. Nastava za učenike male realke, vježbaonice i učiteljske škole održavala se u zgradi pučke škole u neodgovarajućim uvjetima. Školske sobe bile su prepunjene đacima ${ }^{26}$, što je pogodovalo širenju infekcioznih bolesti potvrđujući tezu prema kojoj je „škola oduvijek bila uzrokom prenašanja zaraznih bolesti, osobito dječjih “27.

„Uslijed toga što je španjolska influenca već jako preotela mah među školskom mladeži," nastava na svim petrinjskim školama nije se održavala od 2I. listopada do 9. studenoga 1918. godine. ${ }^{28}$ Slijedom Naputka za školske liječnike srednjih i sličnih škola, za nastavnika higijene u IV. razredima gimnazije imenovan je dr. Rudolf Herceg (I877. - I949.) koji je početkom drugog polugodišta školske godine rg18./rg19. postao i školski liječnik.

Spoznaja o ranjivosti školske populacije te o potrebi redovita liječničkog nadzora zdravstvenog stanja učenika i uvjeta njihova boravka i rada u školi, inicirala je pojačano zanimanje društvene zajednice za ciljanu zdravstvenu zaštitu i poboljšanje socijalno-higijenskog standarda školske djece i mladeži.

Pokrajinska uprava za Hrvatsku i Slavoniju, Odjeljenje za prosvjetu i vjere, uputila je 1922. dopis petrinjskoj realnoj gimnaziji s upitom o stanju higijenskih prilika u školi u odnosu na kapacitet škole i broj učenika, održavanje

\footnotetext{
Zdravstveno stanje u gradu Petrinji 1898, „Banovac“, 1899; 2; 1.

Zvona zvone, majke suze rone, „Hrvatstvo“, 1905; 277; 300.

Inspiciranje, „Banovac“, 1905; 43; 1.

I. Golec: n. d., 174.

F. Vitauš: n. d., 470.

Sve petrinjske škole zatvorene na 14 dana, „Banovac“, 1918; 41; 3.
} 
čistoće, broj djece u razredima, broj zahoda, način ventilacije, grijanja, rasvjete, broj šugave i ušljive djece i dr. U ocjeni higijenskih prilika u školi ravnatelj škole Stjepan Kajba naveo je kao negativne elemente sedamdeset pet učenika u jednom razredu, pri čemu njih pet-šest sjedi u jednoj klupi, nedostatan broj zahoda, nemazanje podova uljem i neredovito krečenje zidova. ${ }^{29}$

Iz izvješća dr. Julija Roksandića (I879. - I959.), predavača higijene i povremenoga školskog liječnika na realnoj gimnaziji, upućenog ravnateljstvu škole 21. siječnja 1925. razabire se da su "prostorije u prizemlju zgrade jedva za silu uporabive" i da je "gombaona potpuno nepodesna za izvođenje tjelovježbe“ budući da "pod ne valja, prozori ne valjaju, vrata ne valjaju (propuh), peć ne valja, a prašina je upravo zagušljiva. Madraci su trošni, a nisu valjda isklopani otkada postoje. Ne bude li moguće za gombaonu naći odgovarajuću prostoriju“, zaključuje dr. Roksandić, ,onda bi bilo bolje da se obustavi podučavanje i tjelovježba nego da se mladež upravo odgaja za tuberkulozu“"30. Iz tablice važnijih bolesti nađenih pregledom 349 učenika realke na početku školske 1924./r925. godine, dr. Roksandić je kod njih I2 dijagnosticirao slaba pluća, kod osam greške na srcu, kod šest bolest nogu i tromost, kod četiri gušavost i bolesti očiju, kod tri tjelesnu nerazvijenost, kod dva učenika tonzilitide i neuralgije, a po jedan učenik imao je skrofulozu vrata, pleuralne adhezije i svinutu hrptenjaču. ${ }^{31}$

Sve veće zanimanje društva i nadležnih državnih tijela za nesmetan rast i razvoj te tjelesno i psihičko zdravlje školske djece rezultiralo je osnivanjem Državne školske poliklinike u Petrinji koja je započela s radom 3. svibnja I925. godine. ${ }^{32}$

\section{Osnivanje DržAVne ŠKolske POLIKLINIKe - VAŽNA ULOGA PRVOGA RAVNATELJA DR. RudOlFA Hercega (3. SVibNJA I925. - 7. VeljaČE 1930.)}

Poliklinika je osnovana zauzimanjem dr. Josipa Locherta, šefa Zdravstvenog odsjeka Vlade za Hrvatsku i Slavoniju, i dr. Andrije Štampara, načelnika Higijenske službe u Ministarstvu narodnoga zdravlja u Beogradu,

29 HR -DASK - SACP - 122 Državna realna gimnazija Petrinja, higijenske prilike u školama, kutija 27, br. 220 i 221 (1922).

30 HR - DASK - SACP - 122 Državna realna gimnazija, izvješće o stanju školskih prostorija realne gimnazije, kutija 28, br. 44. (1925).

31 Isto. Statistički podaci o zdravstvenom stanju učenika, ustanovljeni pregledom početkom škol. god. 1924/25.

32 Školska poliklinika u Petrinji, ,Jedinstvo“, 1925; 23; 3. 
velikana socijalne medicine i javnog zdravstva kojega je koncepcija higijensko-epidemiološke i preventivno-kurativne službe učinila jednim od najutjecajnih ljudi svoga vremena, te inicijativom dr. Rudolfa Hercega (slika I.), tadašnjega petrinjskog fizika i školskog liječnika. ${ }^{33}$ Važnu ulogu u uspostavi njezinih kompleksnih funkcija i u što uspješnijem prevladavanju početnih teškoća imala je i Desanka RistovićŠtampar, ravnateljica Državne školske poliklinike u Zagrebu, koja je u „svemu bila neobično susretljiva i kulantna".34 Kao dokaz tome može nam poslužiti njezino pismeno uvjerenje upućeno 8. svibnja 1925. Inspektoratu Ministarstva narodnog zdravlja u Zagrebu, u kojem konstatira da je „školska poliklinika u Petrinji postavljena i uređena neumornim radom i savjesti

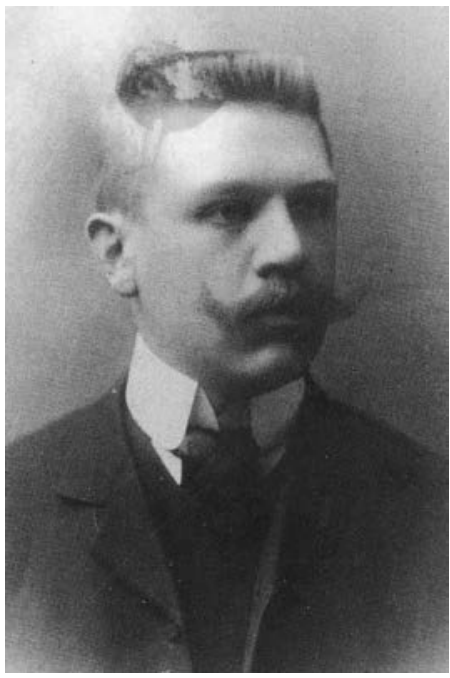

Slika r. Dr. Rudolf Herceg (1877. - 1949.).

Fig I. Rudolf Herceg MD (1877-1949). dr. Hercega“ pa stoga moli i predlaže da se on „imenuje šefom školske poliklinike i školskim liječnikom za sve škole u Petrinji i najbližoj okolici ${ }^{\text {“35 }}$.

U sklopu priprema za osnivanje Poliklinike, „Zemaljska vlada poslala je početkom ožujka 1925. gradskoj općini Petrinja veliku i modernu tzv. Deckerovu baraku, izgrađenu od drveta i impregniranog papira, dugačku trideset metara, široku pet i visoku između tri i četiri i po metra te 70.000 dinara u gotovini za njezino uređenje. Postavljena u dvorište gradske pučke škole (slika 2.), baraka je imala električno osvjetljenje, priključak na gradsku vodovodnu mrežu i dva engleska zahoda.

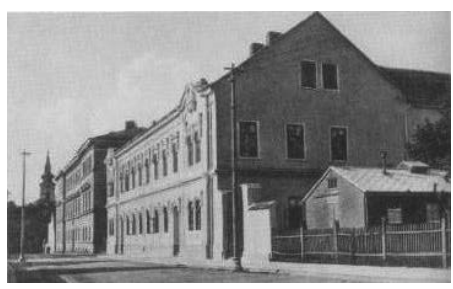

Slika 2. Državna školska poliklinika u Petrinji (r925. 1945.), prva zgrada desno.

Fig 2. State school-polyclinic in Petrinja (1925-1945), the first building on the right. Na njezin ulaz smješten tik do škole, ulazilo se je u čekaonicu ordinacije za

\footnotetext{
Isto.

Isto.

35 HR - HDA - 890, Personalni spisi državnih službenika Zemaljske vlade, Pokrajinske uprave, oblasnih organa Savske Banovine, Banovine Hrvatske i ministarstva NDH, preporuka za namještenje, kutija 183 (1925).
} 
interne i ostale bolesti te laboratorij, a sa nasuprotne strane nalazio se je ulaz u zubarsku ordinaciju i čekaonicu za kupelj sastavljenu od osam tuševa s hladnom i toplom vodom “36. Baraka je sadržavala i posebnu "tamnu sobu“ za pregled očiju i grla, u koju se trebao smjestiti RTG aparat koji je „vlada bezuvjetno trebala što prije poslati, jer se za istim osjećala velika potreba“, sobu za dispanzersku sestru stalno namještenu u Poliklinici, sobu za poslugu, kuhinju i blagovaonicu. Stoga ne začuđuje zadovoljstvo građana Petrinje time što je takva ustanova etablirana u njihovu gradu i nada da će zahvaljujući „njenoj uzornoj čistoći te ukusno i racionalno uređenim prostorijama s novim i modernim medicinskim spravama zdravlje naše djece u najskorijem vremenu znatno kročiti naprijed ${ }^{\text {“37. }}$.

Odmah po osnivanju djelatnici Poliklinike započeli su djelovati na zdravstvenoj zaštiti učenika provodeći sistematske preglede, cijepljenje i liječenje oboljelih, zdravstveni odgoj, higijensko-sanitarni nadzor nad školama, stanovima učenika i ostale aktivnosti iz svoga djelokruga. Početkom svake školske godine obavljani su sistematski pregledi svih učenika osnovnih i srednjih škola i o svakom je učeniku vođen zdravstveni list. Tijekom pregleda svakom su učeniku mjereni visina, težina i obujam prsnog koša te pregledavani srce, pluća, uši, nos i grlo. Ako se dijagnosticirala kakva bolest, o tome se izvješćivalo roditelje učenika. Za bolesti očiju svako je tromjesečje, od početka djelovanja Poliklinike, angažiran po dva dana u ambulanti okulist dr. Vilko Panac (1895. - I975.), asistent u Bolnici milosrdnih sestara iz Zagreba.

Već prva izvješća pokazala su opravdanost osnivanja Poliklinike koja je u razdoblju od lipnja do sredine listopada 1925. „zabilježila ukupno 5215 posjeta. Od unutarnjih bolesti pregledano je 683 djece, očni liječnik pregledao je 69 djece i besplatno izdao 17 naočala, a specijalista za uho, grlo i nos 24 djece. Kroz to vrijeme kupalo se je 4316 djece (pojedina više puta), a ošišana su I22 djeteta" ${ }^{\text {"38 }}$.

Dana 16. ožujka 1926. inspekciju Školske poliklinike obavili su Andrija Štampar, načelnik Odjeljenja za higijenu i socijalnu medicinu Ministarstva narodnog zdravlja, i dr. Berislav Borčić, šef Epidemiološkog zavoda iz Zagreba, te se o njezinu djelovanju „povoljno izrazili i sa potpunim zadovoljstvom konstatirali opći red i uzorno vođenje ${ }^{\text {(339 }}$.

Vidi bilješku broj 32 .

Isto.

Školska poliklinika, ,Jedinstvo“, 1925; 46; 3.

Zdravstvena komisija, ,Jedinstvo“, 1926; 12; 2. 
Nakon što je u Ministarstvu zdravstva isposlovao ,vagon cementa i novac potreban za zidare" ${ }^{40}$, dr. Herceg je u ljeto 1926. obilazio sela petrinjskog kotara zbog uređenja bunara i vrela. Zahvaljujući tome, na njegovu su inicijativu ,uređena tri bunara u Hrastovici i Moštanici, po dva u Blinji i Bijelniku te korito kod Taborišta ${ }^{\text {(441 }}$. Već iduće godine izgrađen je higijenski zahod u Hrastovici, novi bunari u Gorama, Mačkovom selu i Kraljevčanima te ure-

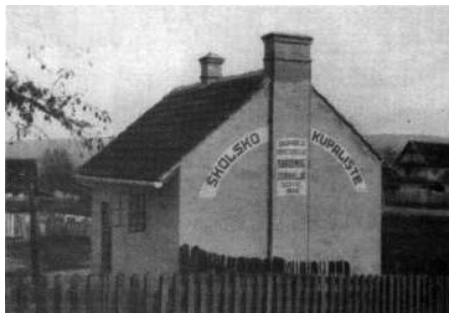

Slika 3. Školsko kupalište u Hrastovici.

Fig 3. The school bathing-place in Hrastovica. đena školska i pučka kupališta u selima nedaleko od Petrinje, Hrastovici i Gorama (slika 3.). ${ }^{42}$

Iz iskaza o radu Državne školske poliklinike za razdoblje od ıo. lipnja I925. do I. srpnja 1926. vidi se da je bio zabilježen I3 o9r posjet, od čega je na internističke preglede i kirurške zahvate otpadalo 20I3, zubarske zahvate Iıо, specijalističke ordinacije okuliste i otorinolaringologa 98, uz 9570 kupanja i „besplatno izdanih 28 pari naočala i lijekova za 2.356 dinara“43.

Dvije godine nakon osnutka Školska poliklinika preuredila je svoje kupalište te je ispred svakog tuša uređena i kabina za presvlačenje. Šef Poliklinike dr. Herceg, ujedno i kotarski sanitetski referent, željeznički liječnik i vršitelj dužnosti gradskog fizika, stavio je kupalište na raspolaganje građanstvu od 17 do 20 sati ponedjeljkom, utorkom i srijedom za žene, a četvrtkom, petkom i subotom za muškarce. Svaki korisnik dobivao je na upotrebu čisti ručnik i komad sapuna. Kao naknadu za kupku korisnici su davali dobrovoljni prinos namijenjen školskoj kuhinji. Zahvaljujući dobrovoljnim novčanim prilozima brojnih građana i udruga, pomoći domaćih tvornica suhomesnatih proizvoda Gavrilović i Krajčinović te inicijalnom prilogu Nj. V. kraljice Marije započela je početkom rujna 1927. u zgradi Poliklinike raditi kuhinja s blagovaonicom za prehranu školske djece (slika 4.). Njezin je pun naziv glasio „Kuhinja za ishranu siromašnih učenika pri Školskoj poliklinici u Petrinji“. U njoj je za školskih dana između šezdeset i stotinu djece svaki dan dobivalo potpuno besplatan ručak. ${ }^{44}$

Uredite svoje bunare, „Jedinstvo“, 1926; 29; 3.

Zdravstvo i higijena, „Jedinstvo“, 1926; 30; 2.

Higijenski rad na selu, „Svijet“, 1929; 13; 302.

43 R. Herceg: Iskaz o radu u drž. školskoj poliklinici u Petrinji od 10. VI. 1925. - 1. VII. 1926., "Jedinstvo“, 1926;30; 2.

44 P. J.: Školska kuhinja u Petrinji, „Jedinstvo“, 1928; 51; 2-3. 
Da su temeljni ustroj i djelovanje Državne školske poliklinike izazivali pozornost medicinskih krugova, dokaz je radni posjet dvojice turskih liječnika, dr. Bakija Beja i dr. Mehmeda Emina, koji su kao izaslanici turske vlade i Društva naroda u Ženevi dana I9. rujna I927. posjetili Polikliniku, novosagrađenu đačku kuhinju i blagovaonicu te kupalište

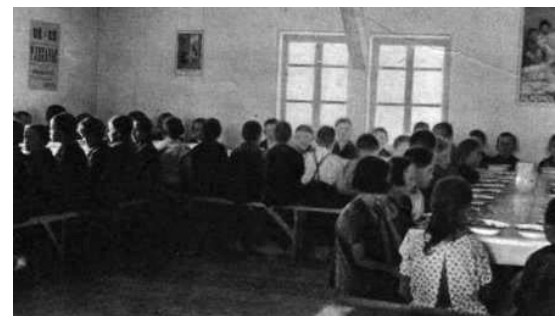

Slika 4. Blagovaonica Školske kuhinje

Fig. 4. The school kitchen dining room. u Gorama, upoznajući se neposredno s principima njihova djelovanja. ${ }^{45}$

U listopadu 1928. u Petrinji i okolici pojavio se šarlah. Dr. Herceg je preko tiska obavijestio građanstvo da „obrambena moć cjepiva vrijedi najdulje godinu dana, pa se stoga preporuča djecu ponovo cijepiti. Školska djeca cijepljena su besplatno, dok su ostali plaćali cjepivo 2 dinara" ${ }^{\text {"46 }}$. Održao je i prosvjetno predavanje o ovoj bolesti (načinima širenja, metodama liječenja, profilaksi) koje je „svojom aktuelnošću privuklo mnoge roditelje“47. Iste godine započeo je u Poliklinici povremeno ordinirati okulist, inače vojni liječnik dr. Viktor A. Đakov.

Koliko su školska djeca ušla u epicentar zdravstvenog interesa govori i podatak da je od I. lipnja 1929. u sklopu Poliklinike započeo djelovati Ured za izbor zvanja ${ }^{48}$ u kojem je dr. Herceg obavljao liječničke preglede, a profesor pedagogije Ilija Opačić (I892. - I94I.) mjerio inteligenciju prema BinetSimonu, određivao psihičku starost djece, davao psihološke savjete i slično. ${ }^{49}$ Baveći se eksperimentalnom pedagogijom, prof. Opačić je na sjednici učiteljskog zbora održanoj 29. lipnja 1925. inzistirao na tome da se pri vježbaonici učiteljske škole osnuje jedan razred za duševno zaostalu i defektnu djecu. ${ }^{50}$ Zauzimao se i za uvođenje jednog sata tjedno dječje psihologije i eksperimentalne pedagogije. ${ }^{51}$ Slijedom toga 1928. osnovao je Društvo dobrote u sklopu kojega je ispitao 437 učenika trećeg i četvrtog razreda osnovne škole i

Strani lekari u Petrinji, ,Jedinstvo“, 1927; 39; 3.

R. Herceg: Škrlet, „Jedinstvo“, 1928; 45; 3.

Prosvjetno predavanje, „Jedinstvo“, 1928;48; 2.

Izbor zvanja, „Primorsko krajiške novine“, 1929; 29; 1.

49 Predavanje prof. Opačića. Kako se mjeri inteligencija kod djece, mladeži i odraslih? , „Primorsko krajiške novine", 1928; 13; 1.

50 HR - DASK - SACP - 126 Učiteljska škola Petrinja. Knjiga 39. Zapisnik Učiteljskog zbora od 11. IV. 1923.

51 HR - DASK - SACP - 126 Učiteljska škola Petrinja. Knjiga 42. Zapisnik Učiteljskog zbora od 29. VI. 1925. 
vježbaonice u Petrinji kako bi ustanovio što djeca smatraju dobrim i koliko je u njih razvijen pojam o dobru. ${ }^{52}$

Početkom rujna 1929. ponovno je u Petrinji boravio dr. Andrija Štampar koji je između ostalih zdravstvenih ustanova pregledao i Školsku polikliniku. Ugodno iznenađen uzornim redom koji je zatekao u njoj, javno je pohvalio organizacijske sposobnosti i medicinsko djelovanje dr. Hercega. Ujedno je dogovorio održavanje popularnih edukativnih predavanja te kinopredstava. Tako je u petrinjskom kinu 24. listopada I929. učiteljskim pripravnicima prikazan film Higijenskog zavoda iz Zagreba Mala Zorica o štetnosti i suzbijanju alkoholizma, a I2. prosinca film Tuberkuloza ili sušica, pri čemu je čist prihod od prodanih ulaznica bio namijenjen đačkoj kuhinji. ${ }^{53}$

Dana I8. listopada i929. upućen je direktorima gimnazije i učiteljske škole u Petrinji hitan dopis Ministarstva prosvjete Kraljevine Jugoslavije, u kojem se traži izjašnjavanje „o odnosu školskih vlasti i školskih poliklinika“ te „mjerama koje bi trebalo preduzeti da se učenicima obezbjedi dobar i uredan liječnički nadzor“. Direktor učiteljske škole Stjepan Figurić odgovorio je da su „učenici pregledavani redovno na početku i svršetku predavanja i kada bi inače ustrebalo. $\mathrm{O}$ učenicima slabijeg zdravlja obavještavan je uvijek direktor koji je onda obavijestio roditelje. Besplatno imaju učenici u poliklinici pregled, vađenje i čišćenje zubi, a za plombiranje zubi plaćaju samo materijal. Ostale lijekove ne dobivaju jer ih poliklinika nema. U tom pogledu trebalo bi zamoliti koju od sadašnjih apoteka da dadu siromašnim učenicima besplatno lijekove, ako direkcija škole potvrdi da je učenik zbilja siromašan. Uopće bi trebalo poraditi da učenici dobivaju u svim apotekama lijekove uz znatan popust na cijeni" ${ }^{\text {54 }}$.

Budući da je dr. Herceg prošao na natječaju raspisanom u prosincu I929. za mjesto upravitelja Zemaljskog zavoda za umobolne u Stenjevcu, preuzimanjem ove funkcije 8 . veljače $1930 .{ }^{55}$ prestao je njegov upraviteljski i stručni rad u petrinjskoj Državnoj školskoj poliklinici, a za vršitelja dužnosti

52 I. Opačić: Društva dobrote, „Napredak“, 1927/28; 68;285-289. O istome: Dubravka Miljković D.: Iz povijesti osnovne škole u Hrvatskoj u razdoblju od 1918. do 1941. "'Odgojne znanosti“, 2007; 1; 141.

53 Ljetopis škole. U: „Državna učiteljska škola u Petrinji - izvještaj za školsku god. 1929/30“, Petrinja, 1930; 7.

54 HR - DASK - SACP - 126 Izvještaj upravitelja učiteljske škole od 21. X. 1929. o funkcioniranju školske poliklinike, kutija 55, br. 1116 (1929).

55 Imenovanja, „Glasnik za staleška zdravstvena pitanja - prilog 'Liječničkog vjesnika'“, 1930; $2 ; 61$. 
upravnika Poliklinike imenovan je specijalist stomatologije dr. Oskar Štern (I90I. - I983.).

\section{Stomatolog DR. Oskar Štern, Drugi Ravnatelj DržAvne ŠKOLSKE POLIKLINIKE (8. VELJAČE - I5. LIPNJA I93O.)}

Stupivši na dužnost stomatologa u petrinjsku Državnu školsku polikliniku I928., dr. Oskar Štern (slika 5.) posebnu je pozornost posvetio preventivnom radu i epidemiologiji karijesa u petrinjskim osnovnim i srednjim školama. U I928. i I929. godini pregledao je 599 učenika realne gimnazije (od I. do IV. i od V. do VIII. razreda) i 28I učenika učiteljske škole te ustanovio da svega 80 učenika (I4 posto) nema kariozne zube. ${ }^{56}$ Ukupno je po-

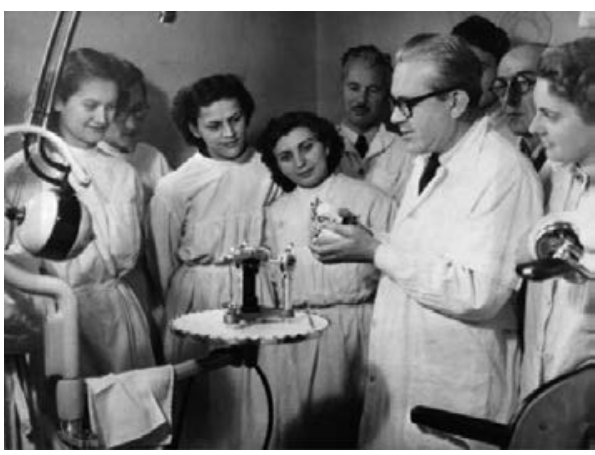

Slika 5. Dr. Oskar Štern (I9oI. - I983.) sa studentima.

Fig 5. Oskar Štern MD (I90I-I983) with students. kvarenih zuba bilo 237I, što praktički znači „da je kod pojedinog djeteta svaki četvrti zub pokvaren!" 57 Posvećujući posebnu važnost sustavnoj sanaciji zuba u školske djece, dr. Štern je i929. ustanovio da je svako dijete iz prvih razreda petrinjskih osnovnih škola u prosjeku trebalo jedan ispun, a da je od 800 ukupno pregledanih učenika te godine, liječenje bilo potrebno kod njih 750. Zbog velikog broja dubokih karijesa i liječenja korijena, liječenjem se nije moglo obuhvatiti svu djecu, tako da je liječenje bilo provedeno kod svega 250 učenika (ukupno rooo ispuna, 4 ispuna po osobi), a zbog nemogućnosti da se sva djeca obuhvate liječenjem, sanacija je zbog velikoga broja dubokih karijesa i liječenja korijena bila provedena kod svega 25 posto učenika. ${ }^{58} \mathrm{U}$ prilog uspješno provedene potpune sanacije, dr. Štern navodi primjer prvog razreda školske vježbaonice u kojem je od 27 učenika zdrave trajne zube imalo svega troje, kod 22 učenika zubi su uspješno sanirani, a dvoje učenika nalazilo se u postupku liječenja. ${ }^{59}$ Djelujući u Petrinji dr. Štern je, prvi put u Hrvatskoj, uveo „sistematske preglede i sustavnu sanaciju zuba školske djece

\footnotetext{
56 O. Štern: Njega zubi školske mladeži, „Glasnik centralnog higijenskog zavoda“, 1932; 1-2; 66-78.

57 Isto, 69.

58 Isto, 73.

59 Isto.
} 
po planskoj koncepciji prof. Kantorovicza"600. Posebna je vrijednost njegova rada u tome što je u spomenutom članku objavio analogne rezultate o prevalenciji karijesa i stupnju sanacije zubâ kod školske mladeži u Petrinji te nekim europskim gradovima, npr. u Berlinu, Luzernu i Strassburgu, a poglavito u Bonnu gdje je I929. na svakoga učenika trebala I,2 plomba pa je zahvaljujući tome sanirano 83 posto slučajeva, a u isto su vrijeme u Petrinji na svakoga učenika trebale 4 plombe, zbog čega je sanacija provedena kod svega 25 posto učenika. ${ }^{61}$

Kod saniranih učenika petrinjske učiteljske škole omjer između izvađenih, liječenih i punjenih zuba bio je r930. godine I : I :5,5, a kod učenika srednjih škola u Bonnu taj omjer tada iznosio $\mathrm{I}: 3: 39$, što pokazuje „da je u Bonnu broj liječenih i extrahiranih zuba neprispodobivo manji srazmjerno prema punjenim zubima nego u Petrinji“62.

U Izvještaju o stanju zdravlja učenika učiteljske škole u Petrinji za školsku godinu I929./I930. dr. Štern navodi kako je tijekom godine zubarska ambulanta imala oko I200 posjeta, pri čemu je učenicima popravljeno 400 zuba. ${ }^{63}$ Tijekom školske godine I930./I93I. zubnu je ambulantu posjetilo 2365 učenika učiteljske škole, pri čemu je napravljeno 846 plombi i izvađena 284 zuba. ${ }^{64}$ U istom razdoblju zubnu ambulantu posjetilo je 747 učenika realne gimnazije kojima je plombirano 257 , a izvađeno 105 zuba. ${ }^{65}$

Dana 3. svibnja I929. prigodno je obilježen Prvi dan borbe protiv tuberkuloze na kojem je nastavnik higijene na realnoj gimnaziji dr. Julije Roksandić učenicima te škole održao predavanje o tuberkulozi i sredstvima kojima se vodi borba protiv nje. Nakon predavanja učenicima su podijeljeni letci koje je poslao Higijenski zavod i Društvo za suzbijanje tuberkuloze iz Zagreba. ${ }^{66}$ Prema uputama Lige protiv tuberkuloze iz Beograda i Društva za suzbijanje tuberkuloze iz Zagreba, u predavanju je istaknuta preventivna vrijednost sunca, zraka i čistoće te je slijedom toga Trećeg dana borbe protiv tuberkuloze, 5. svibnja i929. dnevna nastava održana u prirodi.

60 I. Škrinjarić: Šezdeset godina od pojave prve primarne publikacije iz dječje stomatologije u Hrvatskoj, „Acta Stomatologica Croatica“, 1992; 3; 229.

O. Štern: n. d., 73.

62 Isto, 72.

63 O. Štern: Izvještaj o stanju zdravlja učenika, U: „Izvještaj Državne učiteljske škole u Petrinji za školsku godinu 1929 /30.“, Petrinja, 1930; 22.

64 Isto.

65 Isto.

66 HR - DASK - SACP - 122 Realna gimnazija u Petrinji, dani borbe protiv tuberkuloze, kutija 32, br. 247 (1930). 
Nakon odlaska dr. Šterna iz Petrinje u srpnju 193ı., zubna ambulanta prestala je s radom ,jer je mjesto zubnog liječnika budžetom reducirano. Urgentni slučajevi, kao i potpuno siromašni učenici upućivani su u Školsku polikliniku u Zagreb ili ovdašnjem privatnom zubaru dr. Juliju Roksandiću koji je takve slučajave besplatno kurirao"67. Prestankom rada zubne ambulante pri petrinjskoj Školskoj poliklinici, školska populacija izgubila je puno, i na planu edukacije o ispravnoj njezi zuba i sprječavanju njihova kvarenja, i na planu sanacije pokvarenih zuba, to više što je karijes kod školske djece bio vrlo raširen.

\section{INTERNist DR. Bogdan Vorkapić, tReći RAVNATELJ DržAVNe ŠKOLSKE POLIKLINIKE (I6. LIPNJA I930. - I9. SRPNJA I94I.)}

Dana I. lipnja 1930. dužnost kotarskoga sanitetskog referenta za Petrinju, a ı6. lipnja 1930. i upravljanje Državnom školskom poliklinikom preuzeo je internist dr. Bogdan Vorkapić (I893. - I950., slika 6.). Početkom školske godine 1930./193I., obavio je sistematski pregled svih učenika realne gimnazije. Od 248 pregledanih učenika, bolesti srca dijagnosticirao je kod I6 učenika, bolesti pluća kod 6o, očne bolesti kod II, preboljeli rahitis kod šest učenika, a kod dva učenika ustanovio je gušu. Đačka kupaonica radila je tijekom cijele školske godine, jedanput tjedno za učenike, a jedanput tjedno za učenice. Ukupan broj učeničkih kupanja iznosio je $1850 .{ }^{68} \mathrm{Kada}$ je riječ o stanju zdravlja učenika učiteljske škole, sistematskim su pregledom bila obuhvaćena I04 učenika, pri čemu je kod njih

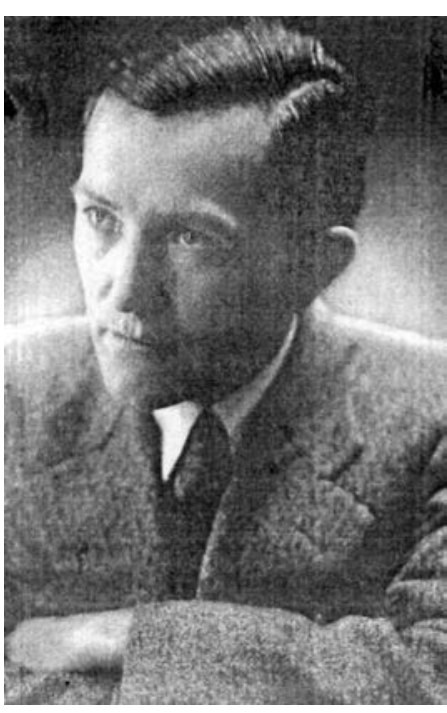

Slika 6. Dr. Bogdan Vorkapić (1893. - 1950.).

Fig 6. Bogdan Vorkapić MD (1839-1950). 20 nađena srčana greška, kod 38 defekt na plućima, kod 24 abnormalni vid,

67 B. Vorkapić: Izvještaj o stanju zdravlja učenika, U: „Izvještaj Učiteljske škole u Petrinji za školsku godinu 1930/31.“, Petrinja, 1931;23. Prema drugom izvoru, dr. Roksandić je „siromašnijim učenicima zube liječio badava, a imućnijima uz znatan popust“. Više u: Dvanaestgodišnje službovanje dra. J. Roksandića kao nastavnika higijene, „Jedinstvo“, 29. IX. 1934., 3.

68 B. Vorkapić: Školska poliklinika, U: „Izvještaj drž. niže realne gimnazije u Petrinji za školsku godinu 1930/31“,. Petrinja, 1931; 18. 
kod šest preboljeli rahitis i kod četiri struma. ${ }^{69}$ Obavljeno je $38 \mathrm{r} 3$ ambulantnih pregleda, pri čemu je 666 pregleda obavljeno zbog internih bolesti, 720 zbog bolesti uha, nosa i grla, 4II zbog bolesti očiju, a 20I4 zbog kirurških bolesti. Ukupan broj kupanja u kupalištu Petrinja, Hrastovica i Gora iznosio je $5500 .{ }^{70} \mathrm{Od} 248$ učenika gimnazije i 194 učenika učiteljske škole, njih 47 bilo je slabo uhranjeno (Io,6 posto), a u školskoj kuhinji svakodnevno, uključujući nedjelje i praznike, ručak i večeru imalo je potpuno besplatno II učenika, 28 učenika s novčanim prilogom od 50 do Ioo dinara mjesečno, a samo besplatan ručak imalo je 70 učenika vježbaonice. ${ }^{71}$ Ručak se uglavnom sastojao od variva, kruha i proizvoda Gavrilovićeve tvornice, a sav rad u kuhinji i nadzor nad djecom obavljao se dežurstvima učitelja i učiteljica osnovne škole u Petrinji. ${ }^{22}$

Školska kuhinja izdržavala se i dobrovoljnim prilozima petrinjskih građana te naturalnim prinosima koje su u nju dopremali stanovnici pojedinih okolnih sela. U tu je svrhu dr. Vorkapić upućivao pismene apele upravama okolnih sela sa zamolbom da pomognu prehranu siromašnih učenika u novcu ili naturi. Tako je 1930., tijekom koje je Poliklinika priredila 30000 obroka, selo Drenčina „poslalo 800 kg krumpira, 40 kg graha, 30 kg crvenog luka i nešto češnjaka, 15 glava zelja, Češko selo 750 kg krumpira, 4 kg masti, 2 kg kaše, 8 vijenaca luka, $150 \mathrm{~kg}$ graha, 577 dinara u novcu, a selo Križ $400 \mathrm{~kg}$ krumpira, $50 \mathrm{~kg}$ graha i 8 vijenaca crvenog luka"73.

Iz dopisa koji je Prosvjetnom odjelu Kraljevske banske uprave Savske banovine u Zagrebu 1931. uputio tadašnji direktor petrinjske gimnazije Antun Miloš, razabire se da đačka kuhinja djeluje uz Školsku polikliniku od rujna do lipnja mjeseca, da je vodi dr. Bogdan Vorkapić, da se u njoj hrane učenici gimnazije, učiteljske i osnovne škole i da se sredstva za njezino uzdržavanje sabiru iz tri izvora: „I) dobrovoljnih prinosa građanstva u novcu i naravi, 2) minimalnih odšteta za hranu kod nešto bolje situiranih učenika, 3) iz redovitih prihoda Poliklinike, te da bi ista za svoje normalno funkcioniranje trebala pomoć od 2.000 dinara mjesečno."77

Nakon provedenih liječničkih pregleda, dr. Vorkapić odabirao je učenike koji će biti upućivani u ferijalne kolonije (primorske i planinske) koje je

\footnotetext{
Vidi bilješku br. 67.

Vidi bilješku br. 68.

Vidi bilješke br. 67 i 68 .

Isto.

Školska poliklinika otpočela s prehranom školske djece, „Hrvatske novine“, 1930; 47; 3.

HR - ASK - SACP - 126 Učiteljska škola u Petrinji, uzdržavanje đačke kuhinje, kutija 57, br. 413 (1931).
} 
osnovao Higijenski zavod sa Školom narodnog zdravlja. Kolonije su bile pod stalnim nadzorom liječnika, osiguravale su pet obroka dnevno i provedbu „sistematskog rada na higijenskom i fizičkom odgoju članova uz razne igre i športove za jačanje zdravlja.“ U kolonije su primani samo zdravi učenici „koji se žele odmoriti i oporaviti te ojačati svoje zdravlje.“ Pritom su „slabunjavi, anemični i nervozni učenici“ upućivani u planinske kolonije, a u primorske kolonije „nisu upućivani učenici koji su imali ili još imaju barem mali proces na plućima"75.

Broj odabranih učenika ovisio je o raspoloživim financijskim sredstvima, među kojima su najznačajnija sredstva dobivena od kr. Banske uprave, potom iz Fonda za zdravstvenu zaštitu učenika u koji su svi učenici pri upisu uplaćivali 20 dinara. Koliko su sredstva varirala vidljivo je iz podatka da je na kraju školske i930. godine upućen u kolonije Higijenskog zavoda iz Zagreba u Martinšćicu kraj Sušaka, Slovenske Konjice, Kastav ili Lipik 7I učenik gimnazije i učiteljske škole, I93I. godine 47 učenika, a 1935. svega šest. Na te je kolonije učenike vodio nadzorni nastavnik koji je obavlja „nadzor nad socijalnim i moralnim vladanjem učenika“, nastojeći da se „svrha ljetovališta,

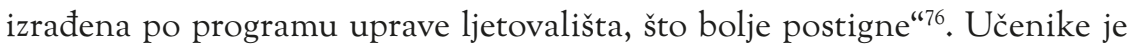
pratila i sestra pomoćnica Barica Janeković (I908. - I987.), koja je od I930. bila zaposlena u Poliklinici. Uz to što je pomagala dr. Vorkapiću pri cijepljenju i drugim medicinskim postupcima, pregledavala je đačke stanove i o uočenim nepravilnostima obavještavala dr. Vorkapića, prema čijim su nalozima nedostaci uklanjani. U Uputstvima za pojedine školske godine isticano je kako „nitko ne smije da primi na stan i hranu učenike gimnazije prije nego za to dobije odobrenje od ovog ravnateljstva. Stanovi stoje pod nadzorom školskog liječnika i imaju u svemu da odgovaraju propisima higijene"77. Slabunjava i anemična djeca liječena su u Poliklinici kvarc-lampom, a u zimskim mjesecima dobivala su svakodnevno besplatno riblje ulje. Očne preglede i korekcije vida jednom u mjesecu obavljao je prim. dr. Vilko Panac, a I938. je kao honorarni dermatolog angažiran specijalist za kožne i spolne bolesti i zaposlenik mjesne Banovinske bolnice dr. Gustav Boltek (I89ı. - I950.).

Da bismo što detaljnije ilustrirali morbiditetnu sliku školske populacije, poslužit ćemo se izvješćima petrinjskih škola za školsku godinu I93I./I932.

75 HR - DASK - SACP - 122 Državna realna gimnazija u Petrinji, osnivanje ferijalnih kolonija, kutija 32, br. 351 (1929).

76 HR - DASK - SACP - 122 Državna realna gimnazija u Petrinji, upute za upis u đačko ljetovalište u Martinšćici, kutija 32, br. 252 (1930).

77 I. Bujanović: Uputstva za školsku 1935/36. godinu, U: „Izvještaj Drž. realne gimnazije u Petrinji 1934/35.“, Petrinja, 1935; 45. 
Prema Izvještaju školske poliklinike za realnu gimnaziju, sistematski je pregledano 229 učenika, pri čemu je njih II bilo sa srčanom greškom, 50 s defektnim plućima (počeci katarnih oboljenja plućnih vrškova, stari ovapnjeni apicitisi ili lakše tuberkulozne upale bronhijalnih i hilusnih žlijezda), I7 s abnormalnim vidom, 6 s preboljelim rahitisom i čak 62 sa strumom, a 40 djece bilo je slabo uhranjeno. U ambulanti Poliklinike obavljeno je I477 pregleda, od čega je ,unutrašnjih pregleda bilo 363 , uha, nosa i grla 178, očiju 4 IO i kirurških ${ }_{52} 6^{\text {"78 }}$.

U učiteljskoj školi, koja je u to vrijeme imala pet razreda, sistematski su pregledana 182 učenika, od kojih je kod 23 pronađena srčana greška, kod 50 razni procesi na plućima, kod 15 abnormalni vid, kod troje preboljeli rahitis i kod četvero struma, a 29 učenika bilo je slabo uhranjeno. Obavljena su 2303 pregleda, od čega je 420 učenika pregledano poradi unutrašnjih bolesti, 443 zbog otorinolaringoloških, 59 r zarad očnih i 849 zbog kirurških bolesti. Srčane mane dijelom su bile urođene - kongenitalne, dijelom akvirirane, no sve su bile dobro kompenzirane i bez komplikacija. Defektnih pluća bilo je razmjerno mnogo, a kao razlog tome navedene su loše higijenske i stambene prilike te slaba i nedovoljna prehrana. Abnormalni vid otpadao je većinom na myope, a struma je bila endemična, parenhimatozna, osrednje veličine, bez poteškoća za disanje ili ma kakvih drugih komplikacija. ${ }^{79}$

Dr. Vorkapić predavao je higijenu na Vinogradarsko-voćarskoj školi i u petim razredima Učiteljske škole. Tijekom školske godine 1934./1935. održao je na učiteljskoj školi 69 sati predavanja ${ }^{80}$, a 1935./1936. godine 44 sata. $^{81}$ Predavanjima je bio obuhvaćen materijal iz opće, osobne i školske higijene, pri čemu je osobita pozornost posvećivana higijeni sela, zaraznim bolestima, tuberkulozi i veneričnim bolestima. Nastavne obveze oduzimale su mu „mnogo raspoloživog vremena za ostali rad na zdravstvenom staranju učenika“ tako da školske godine 1934./I935. „nije mogao biti izvršen sistematski pregled ni u jednom razredu“82. Posvećujući posebnu pozornost tuberkulozi, koja je u to vrijeme bila vrlo raširena, dr. Vorkapić je građanima Petrinje I93I. održao predavanje naslovljeno Tuberkuloza sa socijalnog gledišta, a II. lipnja

78 B. Vorkapić: Izvještaj o stanju zdravlja učenika.U: „Izvještaj niže državne realne gimnazije u Petrinji za školsku godinu 1931/32.“, Petrinja, 1932; 23-24.

79 B. Vorkapić: Izvještaj o stanju zdravlja učenika, U: „Državna učiteljska škola u Petrinji, Izvještaj za školsku godinu 1931/32. „, Petrinja, 1932; 27.

80 B. Vorkapić: Izvještaj o zdravlju učenika - ca, U: „Izvještaj Drž. učiteljske škole u Petrinji za 1934/35. Godinu“, Petrinja, 1935, 29.

81 B. Vorkapić: Izvještaj o stanju zdravlja učenika - ca, U: „Izvještaj Drž. učiteljske škole u Petrinji za 1935/36. godinu. Petrinja," 1936; 17.

82 Vidi bilješku br. 80. 
1939. učenicima Državne realne gimnazije predavanje o tuberkulozi i suzbijanju te bolesti. ${ }^{83}$

Dana I5. siječnja 1932. dr. Vorkapić je u sklopu Školske poliklinike otvorio Savjetovalište za gušave ${ }^{84}$, koje je radilo jednom tjedno, te započeo aktivnost na suzbijanju endemične gušavosti na području njezina djelovanja. U sklopu toga pregledana su ukupno i692 djeteta iz I4 seoskih škola te iz petrinjske realne gimnazije, pri čemu je ustanovljeno da 607 djece ( 35,8 posto) ima gušu. ${ }^{85}$ Dr. Vorkapić je gušavu djecu liječio sisačkom, jodom bogatom mineralnom vodom (popularno zvanom Teslićeva jodna voda); svako je dijete pod kontrolom učitelja pilo tijekom 2I dana po pola litre jodne vode. Nakon završene prve faze i odmora od tri tjedna, nastupila je nova faza pijenja u trajanju od 2I dan, a nakon odmora od 2I dan počela je treća faza. Na ovaj je način svako dijete popilo 3I,5 litru vode koju je tvornica jodne vode Petra Teslića iz Siska besplatno dodijelila Poliklinici. Potpun terapijski uspjeh postignut je kod 237 ( 42 posto), djelomičan kod 287 (5I posto), a neuspjeh kod 40 (7 posto) učenika. ${ }^{86}$ Ǔ̌inke liječenja procijenjene mjerenjem i fotografiranjem stanja guše, dr. Vorkapić je prikazao na izložbi Higijenskog zavoda održanoj u Zagrebu u travnju i svibnju r932. godine. ${ }^{87}$

Uspostavljajući usku suradnju s prosvjetnim djelatnicima koji su sudjelovali u ocjenjivanju školskog uspjeha učenika, dr. Vorkapić bavio se ispitivanjem intelektualnog potencijala gušave djece, ustanovivši da se u skupini gušave djece nalazio znatno manji postotak odličnih i srednjih učenika negoli u zdravoj populaciji. Posvećujući posebnu pozornost valorizaciji psiholoških i intelektualnih sposobnosti učenika, dr. Vorkapić je zapazio da su nakon provedenoga liječenja gušavi učenici znatno popravili školski uspjeh. ${ }^{88}$

Godine I93I. isprobano je djelovanje sisačke jodne vode na strumu i tjelesnu težinu kod 9I učenika u školama Horvati i Krajiška u Zagrebu. Učenici su pili vodu 40 dana i struma se smanjila u 70 posto slučajeva. ${ }^{89}$ Ohrabren

83 Školski ljetopis,U: „Izvještaj Drž. realne gimnazije u Petrinji za šk. 1938/ 39. godinu“, Petrinja, 1939;14.

84 Savjetovalište za gušave, „Jedinstvo“, 1932; 3; 2.

85 B.Vorkapić: Izveštaj Državne školske poliklinike u Petrinji o lečenju endemične gušavosti Sisačkom mineralnom vodom, Petrinja, Higijenski zavod Zagreb,1932; 1-5.

86 Isto, 6-11.

87 Liječenje guše Sisačkom mineralnom vodom, „Sisački glas“, 1932; 16; 3.

88 Vidi bilješku br. 81; 5.

89 M. Vukadinović: Pedeset godina od osnivanja prvog školskog ambulatorija u Zagrebu, U: „50-godišnjica osnutka prvih ustanova za zdravstvenu zaštitu školske djece i omladine u Zagrebu. Sekcija školske medicine ZLH. ZZZ grada Zagreba“, Zagreb, Dispanzer za šk. dj. i oml. DZ „Črnomerec“, 1974; 28. 
postignutim rezultatima, dr. Vorkapić je primjenjivao Teslićevu jodnu vodu i na dijelu odraslih bolesnika s izrazito velikim gušama. Način upotrebe vode bio je isti, ali je dnevna količina konzumirane vode povišena na jednu litru. Rezultati su bili još vidljiviji jer je kod pojedinaca „opseg guše pao za pet, pa čak i za ro $\mathrm{cm}^{\text {"90 }}$.

Godine 1933. pristigao je u Petrinju kamion - auto Škole narodnog zdravlja iz Zagreba pod vodstvom Kamila Brösslera (I90I. - I967.), redatelja i voditelja njezina prosvjetno-propagandnog odjela, autora igranog filma Dva brata: film o sušici (1931.), koji je u okolici Petrinje snimao nekoliko zdravstveno-obrazovnih filmova za Higijenski zavod. ${ }^{91}$ Nastojanjem dr. Vorkapića, kao predsjednika petrinjskog odbora Crvenog križa, održan je krajem I935. u prostorijama Poliklinike višemjesečni tečaj za sanitetsko osoblje i dobrovoljne bolničare i bolničarke. Osim njega, predavači na tečaju bili su dr. Julije Roksandić, dr. Artur Horvat i sestra Barica Janeković. ${ }^{92}$

Ozbiljnijih epidemija u školama u to vrijeme nije bilo, osim lakših slučajeva gripe i ospica, zbog čega je bila prekinuta nastava na vježbaonici od 6 . do 2I. ožujka I935. ${ }^{93}$, a „I4, I5. i I6. ožujka I940. nije se na zahtjev Školske poliklinike držala nastava u učiteljskoj školi zbog pojave oboljenja moždanskih opni među učenicima i raskuživanja razreda“94.

Kao dokaz neprekidna preventivno-kurativnog djelovanja u petrinjskim školama navodimo kako je u školskoj godini I938./1939. dr. Vorkapić sistematski pregledao 54 učenika četvrtih razreda realne gimnazije i pritom zamijetio „dosta karioznih zuba čemu je uzrok taj što Poliklinika već osam godina nema zubnog liječnika te se asanacija zuba uopće ne vrši“95. Ambulantno je tijekom školske godine pregledano 255 učenika, pri čemu su utvrđene srčane mane kod pet učenika, bolesti pluća kod I3, rahitičnost kod tri, malokrvnost kod I8, bolesti grla, nosa i uha kod 84, bolesti očiju kod I2 i kožne bolesti njih kod 26. Internističkih je pregleda bilo 53, kirurških zahvata 34, akutnih infekcioznih oboljenja tri i bolesti zuba četiri. U đačkoj kupaonici okupano je Io20

$90 \quad$ Vidi bilješku br. 78.

91 Snimanje filmova Škole narodnog zdravlja u Petrinji, „Obzor“, 1933; 237; 6. Kao bivši učenik petrinjske preparandije Brössler se založio i za osnivanje Male škole (dječjeg vrtića) u Petrinji 1942. godine.

92 Lijep odziv za poziv u tečajeve za pomoćno sanitetsko osoblje, „Jedinstvo“, 2. XI. 1935., 4.

93 B. Vorkapić: Izvještaj o stanju zdravlja učenika. U: „Državna učiteljska škola u Petrinji“, Petrinja, 1935; 20.

94 Školski ljetopis. U: „Izvještaj Učiteljske škole u Petrinji za školsku godinu 1939 - 40.“, Petrinja, 1940; 11.

95 B. Vorkapić: Stanje zdravlja učenika(ca). U: „Izvještaj drž. realne gimnazije u Petrinji, šk. 1938 - 39. god. Petrinja“, 1939; 28-29. 
djece ( 755 učenika i 265 učenica). „Slabunjavoj djeci podijeljeno je u zimskim mjesecima $5 \mathrm{~kg}$ ribljeg ulja. Kvarc lampom nije liječeno nijedno dijete pošto je stari žižak pregorio, a za nabavku novog nije bilo dovoljno kredita. Pregled đačkih stanova izvršila je sestra pomoćnica Barica Janeković u 74 kuće, pa je sve nepravilnosti dostavila šefu Poliklinike po čijem su naređenju nedostaci uklonjeni i potrebno dovedeno u red“96. U školskoj kuhinji besplatno se hranilo 250 školske siromašne djece, uz napomenu da je „za pravilno funkcioniranje kuhinje, odnosno za ishranu siromašne školske djece i izdavanje više obroka i bolje hrane potrebna veća pomoć Kralj. banske uprave. Većim sumama odobrenim od Kralj. banske uprave u tu svrhu dalo bi se posredstvom školske kuhinje mnogo učiniti za zdravstveni napredak naše školske mladeži, koja je mahom siromašna i čije je školovanje svagda skopčano s materijalnim teškoćama i bijedom“97?

Teškoće s financiranjem djelovanja Državne školske poliklinike, koje su se već krajem dvadesetih godina očitovale u nemogućnosti izdavanja besplatnih lijekova, a početkom tridesetih u nedostatku sredstava za održavanje zubne ambulante ${ }^{98} \mathrm{i}$ u radu školske kuhinje, sredinom tridesetih manifestirale su se u sve manjem broju učenika upućivanih u lječilišta i oporavilišta. U izvješću učiteljske škole za 1933./1934. godinu dr. Vorkapić navodi kako će se „uslijed slabe pomoći od strane Kr. banske uprave moći u banovinskom trošku uputiti ove godine na oporavak u Martinšćicu svega 2 - 3 učenika“999, u izvješću Državne realne gimnazije za 1936./1937. konstatira „kako u ovoj školskoj godini nije Poliklinici doznačena još nikakva pomoć te stoga nisu ni

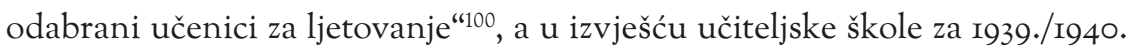
godinu naglašava "kako na ljetovanje nije upućen nijedan učenik“"101.

Vjerojatno su to bili glavni razlozi zbog kojih je 3. listopada 1940. dr. Vorkapić uputio podnesak Odjelu za narodno zdravlje pri Banskoj vlasti

96 Isto.

97 Isto.

98 Izvještavajući o smanjenju prihoda i subvencija petrinjskoj Školskoj poliklinici onodobni je tisak kritizirao činjenicu da „cijeli uređaj zubne stanice, koji je stajao preko 25.000 dinara stoji badava“, a „preko hiljadu i sto učenika i učenica petrinjskih škola ne koristi usluge honorarnog liječnika zubara koji postoji u gradu i koji bi obavljao posao u Poliklinici uz mjesečni honorar od 500 dinara“. Opširnije u članku: Školske poliklinike bez zubara, "Jutarnji list", 27. IX. 1939., 7.

99 B. Vorkapić: Izvještaj o stanju zdravlja učenika, U: „Državna učiteljska škola u Petrinji 1933 - 34. godine“, Petrinja, 1934; 27.

100 B. Vorkapić: Stanje zdravlja učenika, U: „Izvještaj Drž. realne gimnazije u Petrinji šk. 1936 37. god.", Petrinja, 1937; 26.

101 B. Vorkapić: Izvještaj o stanju zdravlja učenika i učenica, U: „Učiteljska škola u Petrinji, Izvještaj za školsku godinu 1939 - 40.", Petrinja, 1940; 24. 
Banovine Hrvatske s molbom za financijsku pripomoć za vođenje i uzdržavanje Poliklinike, koja je na ime pripomoći Poliklinici dodijelila 3500 dinara za IV., V., VI., IX., X., XI. i XII. mjesec 1940. godine. Budući da nije bila dostavljena nikakva pripomoć za mjesece srpanj i kolovoz kada je školski raspust, dr. Vorkapić u svom podnesku navodi kako mu se time čini nepravda jer on „permanentno radi bez obzira na školske ferije, a u VII. i VIII. mjesecu vodi još i svu administraciju i sav posao sestre pomoćnice pošto se ista ta dva mjeseca nalazi u supstituciji pri Dječjem oporavilištu u Lipiku" ${ }^{\text {"102 }}$ (slika 7.). U prilogu podneska dostavlja i prijepis akta koji je još Iz. kolovoza 1936 . Poliklinici uputila Škola narodnog zdravlja iz Zagreba, a u kojem se ističe „kako za vrijeme školskih praznika učenici ne prestaju biti učenicima i kako su prema Zakonu o zdravstvenoj zaštiti učenika, školske poliklinike dužne da se staraju o zaštiti zdravlja svih učenika narodnih, srednjih i stručnih škola za vrijeme cijelog školovanja“"103.

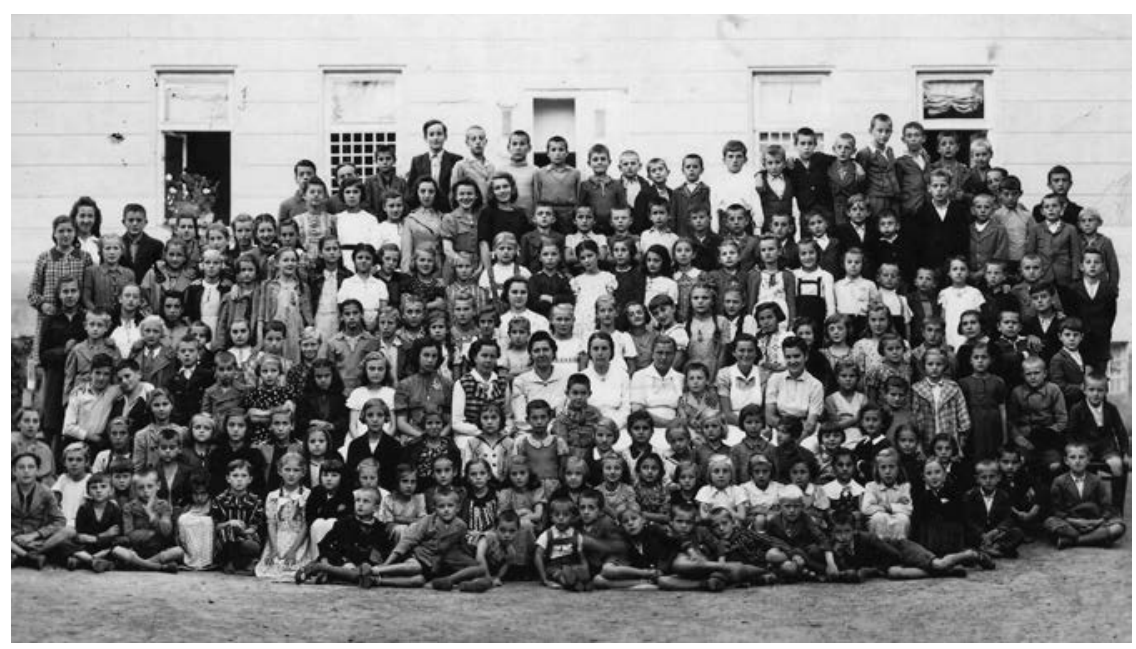

Slika 7. Školska djeca na oporavku u Lipiku, medicinska sestra Barica Janeković sjedi u sredini trećeg reda (u prugastom prsluku).

Fig 7. Schoolchildren recuperating in Lipik, nurse Barica Janekovic is sitting in the middle of the third row (in a striped waistcoat).

Izbijanjem Drugoga svjetskog rata i uspostavom Nezavisne države Hrvatske, dr. Vorkapića su snašle ozbiljne nevolje. Iako je I3. travnja I94I.

\footnotetext{
102 HR - HDA - BHONZ 165/2 Državna školska poliklinika u Petrinji - pripomoć, II - 13427, kutija 15 (1940).

103 Isto.
} 
kod kotarske oblasti u Petrinji položio prisegu vjernosti $\mathrm{NDH}^{104}$, 26. svibnja zbog nacionalne je i vjerske nepodobnosti udaljen iz službe s napomenom kako će njegovu djelatnost obavljati dr. Julije Roksandić, privatni liječnik iz Petrinje ${ }^{105}$, da bi odlukom ministra zdravstva dr. Ivana Petrića 19. srpnja 194I. dr. Vorkapić bio otpušten iz službe bez prava na mirovinu. ${ }^{106}$

\section{Djelovanje ŠKolske POliklinike OD I94I. DO I945.}

Zbog ratnih uvjeta, teškoća u održavanju nastave i nedostatka liječničkog kadra, djelovanje Školske poliklinike sve se teže organizira, a opseg djelatnosti sve se više smanjuje. Da se u Školskoj poliklinici malo radi ili se nimalo ne radi dokaz je Izvješće Državne realne gimnazije za školsku godine r94I. 1942., 1942. - 1943. i 1943. - 1944. (Petrinja, 1944.) i Izvješće Državne učiteljske škole u Petrinji za školske godine 194I. - 1942., 1942. - I943. i 1943. - I944. (Petrinja, 1944.), u kojima nema ni slova o njezinu djelovanju i zdravstvenom stanju učenika, što je od osnutka Državne školske poliklinike bila obvezna rubrika u svim izvješćima.

Od početka rata 194I., u zgradi učiteljske škole bili su „osim ustaških i domobranskih jedinica, nastanjeni i njemački i talijanski vojnici. To vojno osoblje nije držalo nikakav red, nečist je iz zatrpanih zahoda curila na hodnik, sobe se kroz više dana nisu uopće čistile. Tek 6. siječnja 1942. vojska je iselila s I. kata, a I6. ožujka I942. iz prizemlja školske zgrade"107.

Ravnateljstvo Učiteljske škole žalilo se 1943. Ministarstvu prosvjete i mjesnim vlastima na teške uvjete rada, a napose na gradsko poglavarstvo koje nije pokazivalo razumijevanja za iseljenje vojske i izbjeglica iz školske zgrade. ${ }^{108}$

Tijekom 1942. školsko kupalište u Petrinji funkcioniralo je sa sedam tuševa koje su upotrebljavali učenici i građani. I dok je pomoćno kupalište u Gorama dobro radilo, dotle je ono u Hrastovici zbog pomanjkanja drva (ogrjeva) radilo tek povremeno.

Nauku o zdravlju predavao je četvrtim razredima učiteljske škole po jedan sat tjedno dr. Bela Foglar (r899. - 1958.) koji je odlukom vlade NDH bio

104 HR - HDA - 890 Personalni spisi državnih službenika Zemaljske vlade, Pokrajinske uprave, oblasnih organa Savske Banovine, Banovine Hrvatske i ministarstva NDH, prisega Državi Hrvatskoj, kutija 549 (1941).

105 Isto, odluka o udaljenju iz službe i razrješenju dužnosti.

106 Isto, dokument o otpustu iz službe bez prava na mirovinu.

107 I. Golec: n. d., 206.

108 Isto. 
imenovan načelnikom Odjela za zdravstvo grada Petrinje. ${ }^{109}$ Krajem I943. stigao je iz Bednje u Petrinju za kotarskog liječnika dr. Milan Šarić (I9o6. - ?). Dopisom od 24. studenoga I943. dopušteno mu je obavljanje sporedne dužnosti u Školskoj poliklinici i na sudu, ali da to ne bude na štetu njegove redovite dužnosti. Naređenjem Ministarstva zdravstva i Udružbe Janka Tortića od I9. siječnja I944. povjereno mu je „privremeno vršenje dužnosti upravitelja kod Školske poliklinike u Petrinji”"110.

Poliklinika je djelovala do 5. studenoga i945., kada njezinu djelatnost preuzimaju petrinjske zdravstvene ambulante. U srpnju i947. baraka u kojoj je djelovala Školska poliklinika zbog dotrajalosti je demontirana, a prostor na kojemu se nalazila postao je školsko dvorište i rukometno igralište.

Time je završilo jedno svijetlo razdoblje u povijesti petrinjske i hrvatske medicine, u kojem je upravo petrinjska Državna školska poliklinika bila ona zdravstvena ustanova koja je tijekom dva desetljeća neprekidno skrbila o sveobuhvatnoj zdravstvenoj zaštiti školske djece na petrinjskom području.

Zahvaljujući svojim upraviteljima dr. Rudolfu Hercegu, dr. Oskaru Šternu i dr. Bogdanu Vorkapiću, koji su ispravno akceptirali viziju socijalne medicine i preventivnog djelovanja prof. dr. Andrije Štampara, Državna školska poliklinika u Petrinji od svoga je osnivanja razvijala preventivnu i kurativnu djelatnost pružajući školskoj djeci cjelovitu zdravstvenu zaštitu.

Da bi takva zaštita bila što potpunija i efikasnija, u njezino su djelovanje uključivani liječnici raznih specijalnosti i prosvjetni djelatnici (internisti, stomatolozi, okulisti, otorinolaringolozi, dermatolozi, psihopedagozi i dr.), roditelji učenika te društvo u cjelini.

Posebnu vrijednost u djelovanju Školske poliklinike predstavljalo je osnivanje Školskog kupališta (I925.), Kuhinje za ishranu siromašnih učenika (I927.), Školskog i pučkog kupališta u selima Hrastovica i Gora (I927.), Ureda za izbor zvanja (I929.) i Savjetovališta za gušave (I932.) te programski utemeljeno zdravstveno prosvjećivanje u obliku organizacije javnih predavanja, projekcije edukativnih filmova i objavljivanja zdravstveno-prosvjetnih

109 Popis nastavnika, U: „Izvješće Državne učiteljske škole u Petrinji za školsku godinu 1941. 1942., 1942. - 1943. i 1943. - 1944.“, Petrinja, 1944; 3.

110 HR - HDA - 890 Personalni spisi državnih službenika Zemaljske vlade, Pokrajinske uprave, oblasnih organa Savske Banovine, Banovine Hrvatske i ministarstva NDH, Odluka o imenovanju, kutija 490 (1944). 
materijala namijenjenih socijalno-medicinskom odgoju učenika i građana te podizanju razine školskog zdravlja. ${ }^{111}$

Afirmirajući socijalnu osjetljivost, djelatnici Poliklinike u svom su djelovanju posvećivali posebnu pozornost djeci siromašnih roditelja kojoj su besplatno davane naočale, lijekovi i riblje ulje, popravljani zubi i obavljana šišanja te omogućen besplatan oporavak u đačkim ferijalnim kolonijama na moru i planinama.

Skrbeći za prosječno 2000 do 2500 školske djece na godišnjoj razini iz petrinjskih srednjih, stručnih i osnovnih te seoskih škola petrinjskog kotara i boreći se na razne načine za financijska i materijalna sredstva prijeko potrebna za svoje djelovanje, Državna školska poliklinika u Petrinji je u dva desetljeća svoga djelovanja u potpunosti opravdala svoje postojanje. Posvećena javnozdravstvenom radu te zaštiti tjelesnog i mentalnog zdravlja školske djece i omladine, ova samostalna zdravstvena ustanova podignula je ugled petrinjskog zdravstva i pridonijela razvoju hrvatske školske medicine koja se tek sredinom pedesetih godina prošlog stoljeća i osnivanjem domova zdravlja (1954.) etablirala kao zasebna dispanzerska jedinica za zdravstvenu zaštitu učenika.

\section{LITERATURA I IZVORI}

1. Golec I.: Povijest školstva u Petrinji 1700 - 2000. Petrinja: Matica hrvatska, 2000.

2. Golec I.: Petrinjski biografski leksikon. Petrinja: Matica hrvatska, 1999.

3. Hofgräff D, Fatović - Ferenčić S.: Uloga i doprinos Desanke Ristović - Štampar (1882. - 1968.) razvoju Školske poliklinike u Zagrebu (1925. - 1941.). U: Anali Zavoda za znanstveni i umjetnički rad u Osijeku. Zagreb - Osijek, 2012; 28: 9-24.

4. HR - DASK - SACP - 122. Državna realna gimnazija Petrinja.

5. HR - DASK - SACP- 126. Učiteljska škola Petrinja.

6. HR - HDA - 890. Personalni spisi državnih službenika Zemaljske vlade, HR Pokrajinske uprave, oblasnih organa Savske Banovine, Banovine Hrvatske i ministarstva NDH.

7. HR - HDA - 165. Banovina Hrvatska. Odjel za narodno zdravlje i socijalnu politiku.

111 O ulozi zdravstvenog prosvjećivanja koje je u Hrvatskoj u međuratnom razdoblju različitim metodama rada (predavanjima, tečajevima, projekcijama zdravstveno-prosvjetnih filmova i drugim metodama) provodila Škola narodnog zdravlja i njoj podređene ustanove, vrlo iscrpno izvješćuje Željko Dugac u knjizi Kako biti čist i zdrav, Zagreb, „Srednja Europa“, 2010. 
8. Petešić Ć.: Kamilo Brössler: naš Pestalozzi, U: Zbornik za povijest školstva. 24 (1991), str. $145-164$.

9. Vorkapić B.: Izveštaj Državne školske poliklinike u Petrinji o lečenju endemične gušavosti Sisačkom mineralnom vodom. Petrinja: Higijenski zavod Zagreb, 1932.

10. Vukadinović M.: Pedeset godina od osnivanja prvog školskog ambulatorija u Zagrebu. U: 50 - godišnjica osnutka prvih ustanova za zdravstvenu zaštitu školske djece i omladine u Zagrebu. Zagreb: Sekcija školske medicine ZLH. ZZZ grada Zagreba, Dispanzer za šk. dj. i oml. DZ Črnomerec, 1974, 24-33.

\section{SUMMARY}

What has been researched and reconstructed, based on archival documents and data from professional literature, is the activity of the State school-polyclinic in Petrinja, from its foundation in 1925 to its termination in 1945. Key figures taking part in its activity have also been highlighted.

Founded as one of the first school-polyclinics in Croatia, the State school-polyclinic in Petrinja developed complete preventive and curative health activities aimed at school population in Petrinja as well as at pupils from the village schools in Petrinja County. These activities were based on carrying out thorough check-ups, giving school children vaccination, and taking other counter-epidemic measures, providing health and sanitary education, exercising sanitary supervision of schools and pupils' homes, implementing remedial measures in the field, taking extra care of socially handicapped children, providing regular diet and healthy meals for the poorest (who got prescription glasses for free, as well as medicines, fish-liver oil, who got their teeth filled, hair cut and were given the opportunity to recuperate in the youth holiday camps at the seaside and in the mountains.) The activities also encompassed the efficient treatment of the sick, among whom the various infectious and internist diseases (anaemia, undernourishment, struma, rickets) and dental caries were prevalent.

Its twenty-year-old continuous activity aimed at providing school population with health care represents a successful synthesis of preventive and curative health principles based on progressive ideas of social medicine promoted by Andrija Štampar, who was a promoter and reformer of public health service in our regions.

Due to being well-organized and the professional enthusiasm of its managers and staff, the State school-polyclinic in Petrinja efficiently promoted public hygiene and addressed the specific health needs of the school population. While promoting integral health care, maintaining and improving physical and mental health of children and youth in the schools in Petrinja and the other schools nearby, it raised the reputation of health care in Petrinja and contributed to the development of the Croatian school of medicine.

Keywords: dental medicine; Bogdan Vorkapić MD; Oskar Štern MD; Rudolf Herceg MD; public health; school of medicine; school-polyclinic Petrinja. 